\title{
Limits of Understanding in the Study of Lost Martial Arts
}

\section{Epistemological Reflections on the Mediality of Historical Records of Technique and the Status of Modern (Re-)Constructions}

\author{
Eric Burkart, \\ Trier University, FB III, Department of Medieval History \\ burkarte@uni-trier.de
}

Abstract - The paper is organised around the notion of embodied technique. The recent attempts to formulate scientific methodologies for the reconstruction of medieval fighting techniques based on a study of premodern fight books raise questions about the epistemological status of these (re)constructed techniques developed by modern practitioners of Historical European Martial Arts (HEMA). Approaching the subject from a perspective of cultural history and martial arts studies, the following questions are discussed: What is technique and how is it related to practice? How is technique acquired and transmitted? How can technique be recorded? And finally, how can historical records of technique be understood, interpreted and converted into practice?

Following Ben Spatz, technique is defined as the knowledge content of specific practices and the semiotic references between practice, technique, and symbols referring to embodied technique are discussed. By looking at the intersubjective communication of subjective fighting skills and relying on the work of Michael Polanyi, the possibility to record the "tacit knowing" of these skills as explicit knowledge is questioned. Given the low knowledge content of the fight books in regard to the execution of the referenced techniques, modern HEMA techniques therefore are to be addressed as purely modern constructions based on modern fighting practices instead of as reconstructions of medieval technique. The discourses in HEMA are also compared to a similar debate in musicology, where the status and the "authenticity" of attempts to recreate the sound of medieval music based on interpretations of early musical notation systems was vividly discussed until the early 2000 s.

Fighting techniques are furthermore addressed as elements of complex fighting systems that only exist within a given historical culture of fighting and are transformed when transferred to another societal context. 


\section{Keywords - martial arts studies; cultural history; cultures of fighting; martial arts; fighting system; embodied knowledge; embodiment; technique; Ben Spatz; tacit knowing; Michael Polanyi; mediality; hermeneutics of movement}

\section{INTRODUCTION}

Historical research on premodern cultures of fighting and their actual fighting practices is in many ways a challenging endeavour. It differs from intellectual or political history because it has to put more emphasis on embodied practices and the related embodied knowledge. As many diverse sources from the medieval and early modern period prove, this knowledge was an important part of the contemporary discourses but is only indirectly documented in the surviving textual and pictorial records. With the premodern European fight books we have yet a significant body of treatises from the $14^{\text {th }}$ to the $17^{\text {th }}$ century which explicitly focus on techniques of fighting. ${ }^{1}$

While research on embodied knowledge in contemporary cultures of fighting may under certain circumstances call for a form of "carnal sociology", the gathering of information is more complicated if we can only rely on written records of past technique. The study of medieval and early modern cultures of fighting with a focus on embodiment nevertheless seems important, if we consider their relevance for the constitution of social status and the construction of gender and group identities. ${ }^{3}$ To ask what people physically did when they engaged in diverse forms of fighting from convivial wrestling as part of an urban festival culture over various forms of ritualised single combat to actual warfare is therefore a legitimate one. ${ }^{4}$

This research should, however, not be limited to the study of chivalric and aristocratic culture in medieval Europe. Fighting practices were neither limited to the ordo of the bellatores nor can the fight books be generally attributed to a noble milieu. To open up fruitful ways of transhistorical and transcultural comparison, a broader perspective is

I would like to express my sincere thanks to Ben Judkins, Daniel Jaquet, Ben Spatz, Sixt Wetzler, Jacob Deacon, and Jens Peter Kleinau for their important suggestions and critical remarks on this paper.

${ }^{1}$ Leng, Fecht- und Ringbücher; Boffa, Les manuels de combat; Jaquet and others, Late Medieval and Early Modern Fight Books.

2 Wacquant, Body \& Soul. See also studies on Indian Kalarippayattu and Chinese Taijiquan based on ethnographic field work: Zarrilli, When the Body Becomes All Eyes; Frank, Taijiquan and the Search for the Little Old Chinese Man.

${ }^{3}$ See among many other works: Keen, Chivalry; Barber, Tournaments; Tlusty, The Martial Ethic in Early Modern Germany; Ludwig and others, Das Duell; Israel and Jaser, Agon und Distinktion; Ludwig, Das Duell im Alten Reich.

4 Anglo, The Martial Arts of Renaissance Europe, pp. 1-5. 
needed that uses research on cultures of fighting with their related fighting systems as a prism to shed light on wider structures of social meaning and discourse. A possible framework could be the evolving field of martial arts studies ${ }^{5}$ and the adoption of a comparative historical perspective. ${ }^{6}$

This paper therefore approaches the subject from a perspective of cultural history ${ }^{7}$ with its broad understanding of culture focussing on orders of knowledge and meaning. ${ }^{8}$ The point of departure is the recent trend in the scholarly study of medieval cultures of fighting to formulate distinct methodologies for the reconstruction of embodied techniques of combat based on an interpretation of the fight books. ' Without the possibility to study the lost movement culture of the past itself, some scholars turned to methods of experimentation using replicas of medieval weaponry and armour. ${ }^{10}$ This approach is closely connected to various attempts of practitioners and independent researchers to revive medieval fighting systems as a modern practice situated between embodied research, martial arts training and combat sports and designated as Historical European Martial Arts (HEMA) or Western Martial Arts (WMA). ${ }^{11}$

These scholarly methodologies are aiming at a scientifically grounded and thus "more valid" understanding of the techniques described in premodern fight books and reconstructed by practitioners of HEMA. The attempts to discuss and discard but also to provisionally validate modern interpretations of premodern traces of technique raise questions about the epistemological status of the results achieved in this process. Treating embodied technique as knowledge ${ }^{12}$ and drawing upon epistemological and

5 Bowman, Martial Arts Studies. See also the articles of the peer-reviewed open access journal "Martial Arts Studies" founded in 2015 by Paul Bowman and Ben Judkins: <http://www.martialartsstudies.org>, accessed 09.08.2016.

${ }^{6}$ Wetzler, 'Martial Arts Studies as Kulturwissenschaft'. Very similar attempts to codify embodied techniques of combat by the use of written accounts exist in India, China, Japan and among other cultures. The striking similarities between these sources and the European fight books furthermore emphasise the need for a global and comparative perspective on cultures of fighting and the media they produced. See the article of Sixt Wetzler in this issue.

${ }^{7}$ Burke, What is Cultural History?; Daniel, Kompendium Kulturgeschichte; Landwehr, Kulturgeschichte.

${ }^{8}$ Reckwitz, Die Transformation der Kulturtheorien, pp. 84-90.

9 Jaquet and Sørensen, 'Historical European Martial Art - A Crossroad between Academic Research, Martial Heritage Re-creation and Martial Sport Practices'; Price, 'A Proposed Methodology for the Validation of Historical European Martial Arts'; Jaquet, 'Experimenting Historical European Martial Arts, a Scientific Method?'.

10 Jaquet, Expérimenter le maniement des armes à la fin du Moyen Age. See also: Jaquet, Combattre en armure à la fin du Moyen Âge; Jaquet, L'art chevaleresque du combat.

11 Jaquet and Sørensen, 'Historical European Martial Art', pp. 6-9.

12 Spatz, What a Body Can Do. 
hermeneutical considerations, these questions organised around the notion of embodied technique shall be discussed on the following pages. Parallels can be drawn to the studies conducted on medieval music, where a movement of musical performers already emerged around the end of the $19^{\text {th }}$ century. Like in modern HEMA, they used replicas or even original instruments to interpret the early and incomplete musical notation systems in order to recreate the sound of medieval music. This so called Historical Performance (HP) movement dominated the discourse on the sound of medieval music for quite a long time. ${ }^{13}$ However, the status of these modern (re)constructions of early music was vividly discussed among musicologists from the 1980s on and the debate reached its peak in the early 2000s. ${ }^{14}$ Many aspects of the musicological debate read like an anticipation of the discourses on medieval fighting techniques and shall therefore be discussed below.

At the same time, the musicological debate also raises awareness for questions of contemporary cultural identity, medievalism and invented traditions in HEMA. From a perspective of martial arts studies, I therefore argue for the adoption of a twofold ethnographic perspective. On the one hand one has to treat the medieval culture of fighting in which the fight books emerged from a perspective of cultural history. And on the other hand the modern conceptions and imaginations of this historical period have to be seen as a point of reference for HEMA as a contemporary fighting culture which is at the same time dialectically intertwined with the scholarly discourse on medieval cultures of fighting. ${ }^{15}$ While Jaquet and Sørensen distinguish between HEMA (a modern fighting practice) and HEMA studies (scientific and amateur research as basis for the practice of HEMA) ${ }^{16}$, a further analytical distinction could be helpful to reflect the complex interaction between past and present technique. In the following article I shall therefore distinguish between fighting cultures of the past as points of reference for our modern inquiries, their material traces as subjects to our modern interpretation (the fight books and other artefacts), modern conceptions and imaginations of these past fighting cultures (popular images as well as the results of scientific studies) and modern fighting practices (HEMA among other martial arts).

A distinctive feature of the actual scholarly discourse on fight books is that many researchers are themselves practicing HEMA and/or other martial arts. This

${ }^{13}$ Huck, 'Meistererzählungen und Meistergesänge', pp. 69-71.

${ }^{14}$ For a short overview see: Kreutziger-Herr, 'Imagining Medieval Music'; see also: Taruskin, Text and Act, Leech-Wilkinson, The Modern Invention of Medieval Music; Kreutziger-Herr, Ein Traum vom Mittelalter; Butt, Playing with History.

15 While the initial talk given the $5^{\text {th }}$ of July 2016 at the International Medieval Congress in Leeds comprised first thoughts on invented traditions and cultural identities associated with HEMA as a "European" or "Western" martial art (in contrast to the predominant "Eastern" martial arts), I decided to treat these questions separately in another article.

${ }^{16}$ Jaquet and Sørensen, 'Historical European Martial Art', p. 6. 
predominance of "scholarly practitioners" is again very similar to the musicological discourses. Embodied practices like music or martial arts are hard to understand for nonpractitioners who are lacking practical knowledge of the subject. As a practitioner, however, the individual embodied knowledge acquired through former education and training sets the stage for any scientific inquiry and any interpretation of source material. The reconstruction of past technique is therefore first of all an epistemological and hermeneutical problem that has to address the following questions: What is technique and how is it related to practice? How is technique acquired and transmitted? How can technique be recorded? And finally, how can historical records of technique be understood, interpreted and converted into practice?

\section{TECHNIQUE AS KNOWLEDGE}

If we are addressing fight books as traces of a past culture of movement, one of the best suiting concepts still seems to be what the French sociologist Marcel Mauss labelled "techniques of the body". In an article first published in 1935, Mauss defines this term as "the ways in which from society to society men know how to use their bodies"17.

Many authors have worked with this concept since then. One of the latest is Ben Spatz, who treats embodied technique from the point of view of sociology of knowledge:

Technique (...) differs from related concepts like performativity and habitus in that it emphasizes the epistemic dimension of practice. Embodied technique then refers to transmissible and repeatable knowledge of relatively reliable possibilities afforded by human embodiment. ${ }^{18}$

Technique is defined by Spatz as the knowledge content of specific practices. The term practice refers only to concrete instances of actions that are defined by the acting person, the time, and the location of the action. Moments of practice are thus unique and not repeatable. An example Spatz gives for practice is his swimming on a given day, his swimming in a given year, and the swimming in North America during the $20^{\text {th }}$ century. ${ }^{19}$

\footnotetext{
${ }^{17}$ Mauss, 'Body Techniques', p. 95. See also: Mauss, 'Les techniques du corps'.

18 Spatz, What a Body Can Do, p. 16.

19 "Practice, in this sense, is not repeatable. Every moment of practice is unique, no matter how small or large: my swimming on a given day, my swimming in a given year, and the swimming in North America during the twentieth century are all examples of practice that can be studied in their specificity. None can be repeated. As knowledge, on the other hand, technique is precisely repeatable and moreover it is not bound to a particular moment, place, or person. Technique is not ahistorical but transhistorical: It travels across time and space, 'spreading' from society to society, as Mauss observed, and linking diverse practices to one another, whether or not its practitioners are aware of this connection. The question for theorists of practice is then not what does or does not
} 
All these practices are provisionally structured, yet not determined by technique. In contrast to practice, technique is repeatable in varying situations and contexts. And as knowledge, it is not innate, but socially acquired and transmitted. Technique therefore spreads from body to body and from society to society and its status is always hybrid and mixed. ${ }^{20}$

A good example in the case of swimming is the "front crawl", a specific swimming stroke that became popular in Western competitions around the end of the $19^{\text {th }}$ century after it was adopted from Native Americans and further developed by Australian swimmers. The case of the "front crawl" is also telling, because despite its efficiency compared to the widely practiced "breaststroke" it was first rejected by European swimmers as being splashy and "un-European". ${ }^{21}$

This illustrates another aspect highlighted by Spatz, namely that sociocultural identities are essentially structured by technique. ${ }^{22}$ Technique thus has to be seen as a "negotiation between socially defined or symbolic meaning and the concrete possibilities offered by the material world". ${ }^{23}$

At the same time, technique has to be addressed as a field of variation as well within societies as on an individual level. ${ }^{24}$ The practice of specific techniques over time furthermore transforms the body and alters its physical structure. ${ }^{25}$ To what actions and movements a given body is capable, is thus partially depending on the social techniques practiced in a specific region at a specific moment in history.

If we are applying this notion of technique to a study of fight books, we are instantly warned not to conceptualise the past fighting culture in a narrow and essentialist way.

count as an example of a given practice, but rather the extent to which different practices are structured by the same technique." Ibid., p. 41.

${ }^{20}$ Ibid., pp. 30-44.

21 Jinnah, 'Swimming, United States'.

22 Spatz, What a Body Can Do, pp. 36-37, 157-159, 171-214.

23 Ibid., p. 31.

24 "The concept of technique presumes no universal or ideal body. Instead, it approaches embodiment as a field of variation, between individuals and also within the lifetime of an individual being. This field of relative reliability and variation is what affords embodied technique as an area of knowledge." Ibid., p. 43.

25 "In these examples, the physical body itself is transformed by the practice of technique over time, so that the range of what a given body can do is substantially altered. (...) It is therefore no exaggeration to say that different kinds of technique produce different bodies in a literal as well as metaphorical sense. The plasticity of embodiment - the degree to which it can be shaped by technique - is not unlimited. But to whatever extent the anatomy of the body is shaped through technique, physiology can be understood as a form of sedimented agency.” Ibid., p. 56. 
Fight books can be seen as the attempts to organise practical knowledge of embodied techniques designed for various situations of combat. These techniques yet have to be seen as fields of variation. Fighting techniques directly engage with the affordances of two or more human bodies in connection and what Spatz addresses as the "relatively reliable possibilities afforded by human embodiment". But being social techniques closely connected to identities, they cannot be reduced to a simple biomechanical functionality. ${ }^{26}$ As the example of the "front-crawl" shows, we have to keep in mind the complex interaction between social meanings attached to technique and their pragmatic purposes.

Another important factor in the study of a lost movement culture is the transformation of bodies through technique ("sedimented agency"27). One simple example would be weight lifting. Lifting a high weight without prior training may seem impossible at first, but after the practice of technique over time, the movement patterns as well as the physical structure of the body adapt. On a social and historical level this means that what medieval and early modern bodies structured by period technique (including everyday practices as well as specialised training) could do, does not have to be congruent with what our modern bodies can do. ${ }^{28}$

\section{FIGHTING SYSTEMS AS MEANS OF COMMUNICATION FOR THE TRANSMISSION OF TECHNIQUE}

By looking at embodied technique of the past and by qualifying technique as knowledge, we have entered the realm of new cultural history with its knowledge-oriented definition of culture. ${ }^{29} \mathrm{I}$ therefore argue that fighting techniques are to be seen as part of a historical

\footnotetext{
${ }^{26}$ The argument that certain fighting techniques are better than others because of their biomechanic and/or psychological functionality plays an important role in today's martial arts discourses. Though there is no doubt that functionality is a basic prerequisite of fighting techniques, these modern discursive patterns closely connected to the respective practitioner's identities and marketing issues must not dominate our approach towards fighting cultures of the past. In the case of swimming, the basic functional prerequisites of the "breaststroke" and the "front-crawl" would be that their practitioners move in a certain direction and do not drown. The existence of the faster (and thus "more" functional) "front-crawl" did, however, not end the story of the "breaststroke" which is still widely practiced in everyday life as well as in sportive competitions.
}

27 Spatz, What a Body Can Do, p. 56.

28 The impact of sensorimotor knowledge and the limitations and affordances of period clothing, armour and weaponry on the reconstruction of technique was already addressed by Jaquet and Sørensen, 'Historical European Martial Art', pp. 14-15, 20-25; Jaquet, 'Experimenting Historical European Martial Arts, a Scientific Method?', pp. 224-27. Keeping in mind that also the physical structure of bodies has to be historicised by applying Spatz's concept of sedimented agency yet goes one step further.

${ }^{29}$ Reckwitz, Die Transformation der Kulturtheorien, pp. 84-90. 
culture of fighting. A culture of fighting comprises the contemporary discourses, norms and symbolic orders that organise the subjective realities of the fighters and thus enable and restrict their action. Within this framework, the dialectic interaction between technique and practice takes place, technique structuring practice and practice reproducing, adapting and thus altering technique.

A transmission of technique can take place in a situation of implicit or explicit learning. At a basic level, fighters of the past were socialised into certain ways of using their bodies in combat. So if we try to conceptualise the transmission of fighting skills, we are first of all dealing with processes of implicit learning by observation and imitation. For this type of learning, the denomination of technique and the existence of didactical concepts for their transmission are not necessary. Practices of fighting are structured by technique, whether or not there is an explicit communication about it.

However, with the fight books we are facing the surviving traces of an ongoing discourse on competing techniques. They are at the same time relics of explicit learning and education (though fight books are by no means didactic manuals in a modern sense). Experienced fighters or professional instructors condensed their skills into certain concepts of how embodied techniques worked and referred to this knowledge within the fight books. We thus have evidence of a specialised technical language like in the oldest known fight book written at the beginning of the $14^{\text {th }}$ century and conserved in Leeds at the Royal Armouries. The famous manuscript I.33 contains depictions of fighting techniques and descriptions in Latin. Furthermore, technical terms in medieval German are inserted to denominate specific techniques like the "fiddlebow", the "crutch" or the "half-shield". ${ }^{30}$ This indicates that the vernacular denominations of the designated fighting techniques were already used and widespread when they were documented for the first time in a written account.

If we try to conceptualise the semiotic relations between denominations or depictions of technique, (didactic) concepts of technique and the actual fighting practices, we see that the basic pattern is the semiotic triangle ${ }^{31}$ (see fig. 1). A Symbol evokes a thought, the thought refers to an object, and the object is in a mutual relation with the symbol.

\footnotetext{
${ }^{30}$ Leeds, Royal Armouries, ms. I.33. Facsimile edition: Forgeng, The Medieval Art of Swordsmanship.

31 Riemer, Introducing semantics, pp. 13-16.
} 


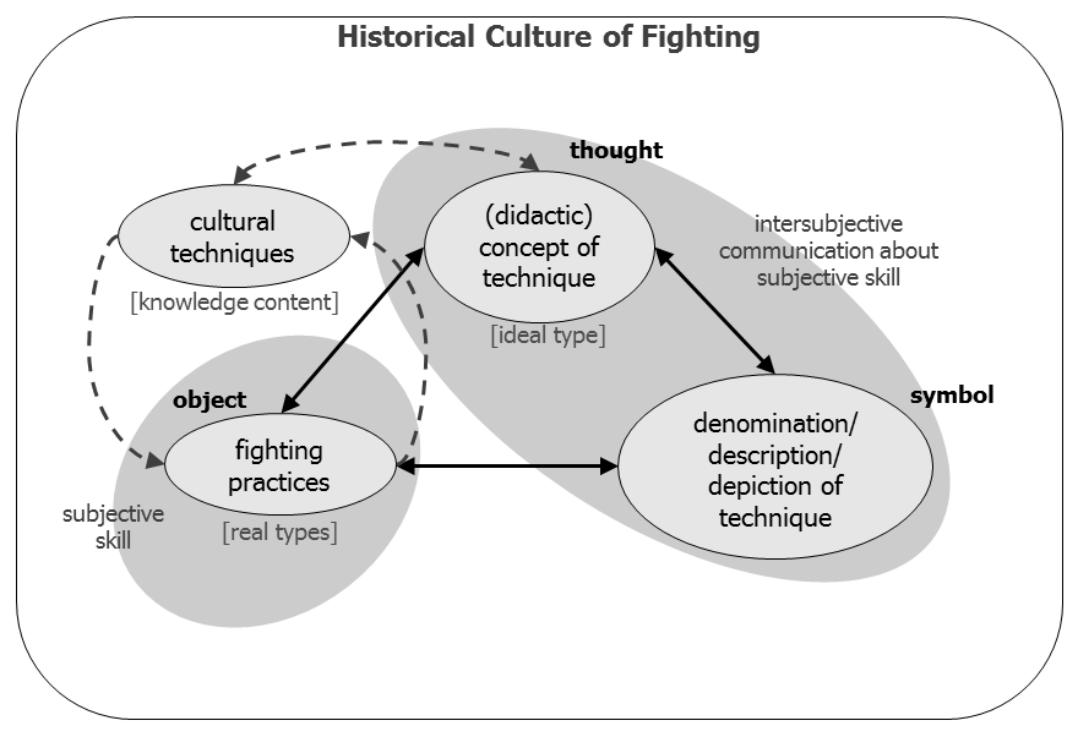

Fig. 1 Historical Culture of Fighting (Author's diagram).

The singular instances of a heterogeneous fighting practice can thus be seen as real types, while a didactic concept of technique represents a Weberian ideal type. In a technical discourse, this concept usually refers to a form of orthopraxis - a "right" way to execute a technique according to the concept. Regarding the transmission technique from one individual to another, we can see that these instances of practice belong to the domain of subjective skill while concepts of how techniques work and the symbols evoking these concepts are part of an intersubjective communication about subjective skills.

To apply the proposed semiotic model to other martial arts, a further distinction between technique as movement and technique as application in combat seems useful. Especially in Asian martial arts, single techniques or combined sets of techniques are organised in motion sequences, often performed without a partner. These "forms" (chin. taolu, jap. kata, kor. pumsae or hyeong) help - just like written accounts - to organise the embodied knowledge of their practitioners and can serve as mnemonic anchors to remember central techniques and their applications. While the movement performed solo in a form is an embodied technique itself, it also serves as an (often polysemous) symbol for technique(s) applied in combat. If we thus look at media using denominations, descriptions and depictions of Asian forms, we have to add another level of semiotic reference in regard to (applied) fighting techniques. 
Many fight books are yet more than just collections of various unrelated references to techniques. They comprise specific selections of techniques and reflect upon their context of application as well as on their interactions as technique and counter technique. We thus have strong indications to refer to them as elements of complex fighting systems. ${ }^{32}$

As a fighting system I would like to designate a complex phenomenon, both on a technical as on a social level. On a technical level, it is a selection of techniques based on a set of assumptions about the likely situations of combat or combat related performances the practitioners of a specific system are preparing for. These assumptions are part of the discursive patterns of a historical culture of fighting in which the fighting system evolved. Yet, the concrete structure of a specific system is based on multiple factors: What is the anticipated situation of combat (sportive competition, military confrontation, ritualised duel, spontaneous self-defence, etc.)? What likely threats are identified (unarmed attackers, fights with bladed weapons, with guns/projectile weapons, against multiple opponents)? How are the physical and mental prerequisites of the practitioners conceptualised? What equipment is required to use the system? How much time is available for the formation of practitioners? Which social norms are to be observed in the fight and what are the likely consequences of their violation? How is a certain behaviour during a fight (and the use of specific techniques) related to the social norms in force and the social identities at stake? ${ }^{33}$ Based on these and multiple other settings in combination with strategic and tactical considerations, a specific system evolves naturally or is intentionally designed and adapted within a given historical culture of fighting.

But, being a cultural phenomenon, these selections of techniques and strategies are based on a specific mind-set that symbolically organises the world of the practitioners and establishes distinct patterns of meaning. The main frame of a fighting system is therefore a set of assumptions on the nature of the anticipated combat itself. It is a model for reality, reduced in complexity and formulated in the terms of a struggle between success and defeat, or even - life and death.

Fighting systems exist as a form of cultural knowledge, whether there are competing systems within one society and an explicit discourse on ways of fighting or not. Fight books then have to be regarded as medial attempts to codify explicitly formulated fighting systems, which - given the ultimate unpredictability of actual fights - can only present ideal-type solutions to ideal-type threats. A specific fighting system therefore serves as an (often didactic) tool to reduce complexity and to facilitate communication. By the use of a system, the contingent situation of combat becomes describable and manageable for its practitioners.

\footnotetext{
32 Burkart, 'Den Kampf anhalten', pp. 176-78; Burkart, 'Body Techniques of Combat'.

33 On the connection between social norms and identities see: Burkart, 'Die Aufzeichnung des Nicht-Sagbaren', pp. 266-72.
} 
A related issue in the field of martial arts studies is the question how to define our key concept: what is a martial art? ${ }^{34}$ While this question will need further discussion, I would like to shortly outline the following proposition which seems at least a suitable tool for treating the content of premodern fight books: A martial art ${ }^{35}$ is a social institution ${ }^{36}$ organising different fields of knowledge around a fighting system. As social institutions, martial arts organise and reproduce ${ }^{37}$ but also transform knowledge associated with, but not limited to practices of fighting. To varying extents, they combine further dimensions of social meaning and related areas of knowledge and technique, including the preparation for violent conflict, play and competitive sports, performance, transcendent goals, health care $^{38}$ but also social identities ${ }^{39}$, self-fashioning ${ }^{40}$ and economic aspects. ${ }^{41}$

By distinguishing between the martial art as social institution and the fighting system as an area of knowledge, there would also be no need to conceptually separate "realistic" or "battlefield-oriented" from "sportive", "playful" or "meditative" martial arts. The selection of techniques and their intended outcome is based on the discursive assumptions on the anticipated situation of fighting or combat related performance. The differences between a bladed Filipino martial art, hyper-real lightsabre fencing, chivalric tournaments, a military close quarters combat system, Olympic boxing and Hans Talhofers way of preparing young noblemen for a judicial duel could then be articulated by describing the social meanings attached to the institution in combination with the

34 Wetzler, 'Vergleichende Kampfkunstwissenschaft als historisch-kulturwissenschaftliche Disziplin'; Wetzler, 'Martial Arts Studies as Kulturwissenschaft'; Judkins, 'The Seven Forms of Lightsaber Combat'.

35 The term "art" here has to be understood in its pragmatic sense referring to craftsmanship or skilful execution of technique instead of referring to primarily aesthetic dimensions of human expression. The designation "martial arts" is therefore used in a wide sense as an umbrella term. Burkart, 'Die Aufzeichnung des Nicht-Sagbaren', pp. 257-61; Wetzler, 'Martial Arts Studies as Kulturwissenschaft', p. 25; Burkart, 'The Autograph of an Erudite Martial Artist', pp. 455-56.

36 "Ultimately this discussion suggests that a set of activities functions as a martial art not because of its historical authenticity or connection to 'real-world' combat. Rather, the martial arts have always been defined primarily through their modes of social organization and the individual, group and systemic roles that they play. At heart they are social institutions rather than collections of isolated techniques." Judkins, p. 10. Cf. also Bowman, pp. 6-18.

37 Wetzler, 'Martial Arts Studies as Kulturwissenschaft', p. 24.

38 Ibid., pp. 25-26.

39 Spatz, What a Body Can Do, pp. 50-56.

${ }^{40}$ Burkart, 'Die Aufzeichnung des Nicht-Sagbaren', p. 272; Burkart, 'The Autograph of an Erudite Martial Artist', p. 477.

${ }^{41}$ Judkins, 'The Seven Forms of Lightsaber Combat', p. 19. 
anticipated situations of combat and their associated norms, for which the practitioners are preparing by training a distinct set of techniques.

\section{RECORDING TECHNIQUE}

Practice is fleeting and not repeatable. Technique is transmissible and travels through time and space. But it is the very nature of technique as a form of knowledge to be transformed in this process. To conduct historical research on embodied technique we are thus depending on cultural artefacts of a given period that can be interpreted as traces of past practices structured by technique. An important question is therefore how technique can be recorded by the use of different media before the invention of celluloid film. Linked with it is the hermeneutical problem of how to understand these media and read them as traces of past technique.

I tried to show the difference between subjective practice structured by technique and an active communication about subjective skills. In a face-to-face situation of instruction this subjective skill can be translated into a description of how a technique works. This description can be accompanied by a demonstration and a correction of the apprentice's movements. ${ }^{42}$ In the fight books we have yet only the surviving relics of this communication process. Left over are only textual references to techniques, sometimes accompanied by descriptions and single or rarely serial depictions of crucial moments in the execution of a technique. ${ }^{43}$

Following the works of Michael Polanyi we yet have to distinguish between explicit and implicit knowledge. The embodied techniques of competent fighters and instructors thus represent a form of "tacit knowing" that is bound to personal experience and cannot be fully verbalised as a form of explicit knowledge. ${ }^{44}$

42 For several quotations from fight books reflecting on this way of transmitting skills cf. Jaquet, 'Experimenting Historical European Martial Arts, a Scientific Method?', pp. 216-17.

43 Sometimes these references are also encoded to ensure that only initiates could understand them and to protect the knowledge on fighting techniques. Cf. Burkart, 'The Autograph of an Erudite Martial Artist', pp. 459-60. Especially the early handwritten fight books from the $14^{\text {th }}$ and $15^{\text {th }}$ century represent a very heterogeneous corpus of sources. These artefacts were unique pieces designed for specific addressees or intended for personal use instead of being commodities for sale like the printed fight books from the $16^{\text {th }}$ and $17^{\text {th }}$ century. Therefore, the evoked techniques are not necessarily described and explained within the early fight books but sometimes only referenced or even encoded. These books mainly served the purpose of organising practical knowledge of their makers and possessors and were not supposed to transmit this knowledge to non-initiates and uninformed third parties.

44 Polanyi, Personal Knowledge, pp. 49-50. 
Rules of an art can be useful, but they do not determine the practice of an art; they are maxims, which can serve as a guide to an art only if they can be integrated into practical knowledge of the art. They cannot replace this knowledge. (...) An art which cannot be specified in detail cannot be transmitted by prescription, since no prescription for it exists. It can be passed on only by example from master to apprentice. This restricts the range of diffusion to that of personal contacts. ${ }^{45}$

By the attempt to record fighting techniques by the use of any medium, the most important part of the actual knowledge is lost. What is still accessible are denominations, depictions or descriptions as symbols referring to embodied technique. The most vital part of this knowledge yet only spreads from body to body and cannot be fully enshrined in any medium.

\section{INTERPRETING RECORDS OF TECHNIQUE}

If we want to interpret fight books as traces of past technique and proceed from the symbols over the concepts towards an execution of technique as actual practice, we are facing many difficulties that I will try to address as "limits of understanding".

Returning to the diagram (fig. 1), we face the problem, that the dialectic practicetechnique-cycle vanished with the living medieval population. The fighting culture of the past also no longer exists. The surviving fight books contain symbols for complex embodied techniques. However, what the fight books do not or only partially contain are the concepts behind the referenced techniques. Sometimes the authors tried to describe these concepts. Without the relation to practice - as Polanyi points out - these concepts yet mostly remain cryptic and underdetermined.

The most important part of medieval technique as knowledge is thus lost forever. It died with its practitioners, and the fight books are only fossil remains like the bones of a dinosaur converted from living organic tissue into a mineralised trace of the once living structure. If we want to make this dinosaur walk again, we depend on working assumptions developed on the observation of living creatures.

By interpreting fight books, we are thus entering a hermeneutical circle:

The hermeneutical circle is one of the most fundamental and contentious doctrines of hermeneutical theory. In its most basic form in contemporary hermeneutics, it is the idea that we always understand or interpret out of some presuppositions. (...) In both versions, the basic

${ }^{45}$ Ibid., pp. 50, 53. 
idea is the same, namely that there is no such thing as an understanding without presuppositions. ${ }^{46}$

If the actual knowledge content of the fight books in regard to embodied knowledge is rather low, the crucial question is: where does the interpreter's additional knowledge come from, which is necessary to translate traces of technique in imaginations of technique and actual practice? The sensitivity to these sort of questions in scholarly discourses has increased rapidly with the reflexive and the interpretive turn in cultural theory. ${ }^{47}$

In relation to the fight books, this means that our modern fighting culture sets the stage for any interpretation, which is always based on modern technique and modern practice. If we try to interpret the symbols and descriptions in the fight books as references to past technique, this is only possible in relation to modern technique (see fig. 2).

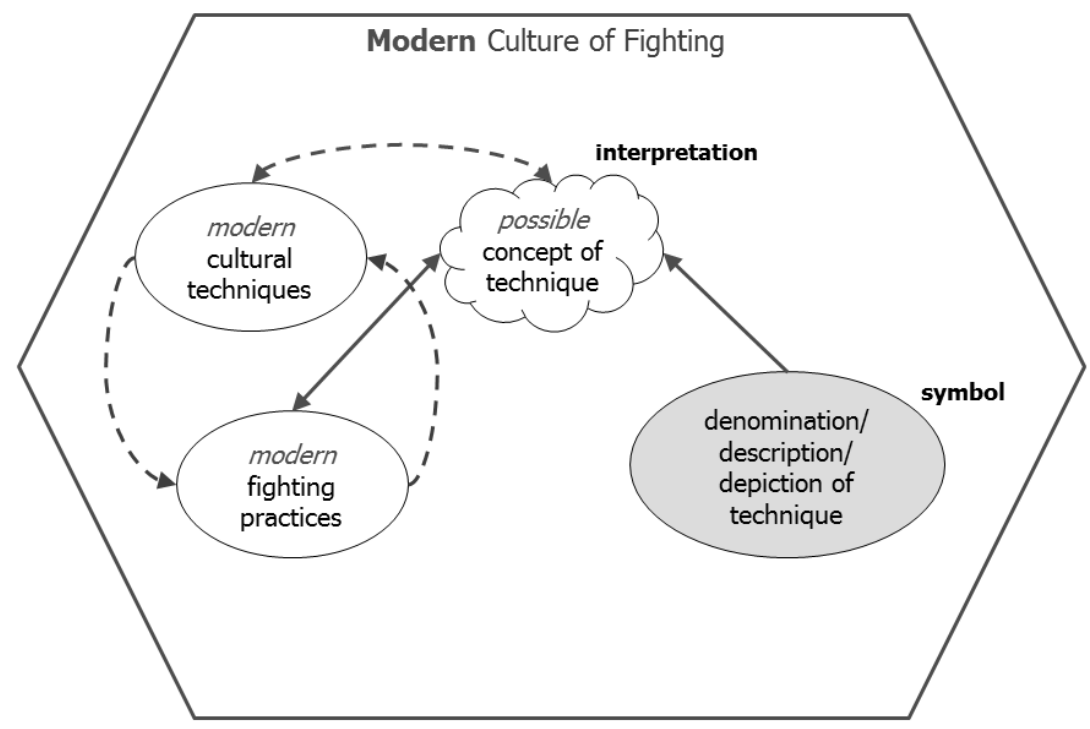

Fig. 2 Modern Culture of Figbting (Author's diagram).

This leads us directly to the initial question on the status of modern attempts to recreate medieval fighting techniques and the role of scientific methodologies. Especially Daniel Jaquet and Claus Sørensen in collaboration with Fabrice Cognot have pointed out various

\footnotetext{
46 Grondin, 'The Hermeneutical Circle', p. 299.

47 Bachmann-Medick, Cultural Turns, pp. 39-71, 103-130.
} 
pitfalls in the ongoing interpretation of fight books, trying to bridge the gap between scholarly research and the practice of HEMA. Their intention is to make the embodied knowledge gained by practitioners through continuous experience in swordplay accessible to a scientific study of fight books. Among other pitfalls, the authors point to the use of bad transcriptions and poor translations of the source material, a lack of considerations concerning the intended audiences and the historical context of the fight books, the use of modern sporting equipment and insufficient consideration of the situations of use, for which the described techniques once were intended. ${ }^{48}$

The authors furthermore distinguish between "experiencing" a martial gesture and "experimenting" it as part of a research process. ${ }^{49} \mathrm{HEMA}$ is here related to experimental archaeology, though the authors point out that the criteria for defining the actual HEMA practice as a form of research are usually not met. Qualifying HEMA as a form of experimental archaeology instead of just as experiencing swordplay, would require that the activities be based on an inquiry, follow a distinct methodology, produce assessable data and that the results are published according to academic standards. ${ }^{50} \mathrm{~A}$ case study concerning the execution of the technique "Flügelhau" aiming to meet these standards was conducted by Jaquet. ${ }^{51}$

Though Jaquet and Sørensen distinguish between different approaches of experimental archaeology, including its more exploratory forms, there is yet one problem if we want to turn HEMA into a scientific experiment aiming at the reconstruction of past technique. Experimental archaeology is for good reasons mainly concerned with artefact production and artefact use. If we compare the experimental set up to a mathematical equation, we have the constant properties of the used materials while the human practice represents the unknown factor that led to a given surviving artefact or to given wear marks on artefacts.

We yet have to differentiate between the reconstruction of technique interacting with the material world and technique interacting with mind and body of other socialised human beings, that is technique interacting with technique. While conducting experiments on the destructive potential of different sword types, on the protective capacities of period armour or on the implications of wearing armour for locomotion and energy $\operatorname{cost}^{52}$ is perfectly in line with the concept of experimental archaeology, the reconstruction of

\footnotetext{
48 Jaquet and Sørensen, 'Historical European Martial Art', pp. 10-15, 20-28.

${ }^{49}$ Ibid., pp. 16-18. This line of thought is further developed in: Jaquet, 'Experimenting Historical European Martial Arts, a Scientific Method?'; Jaquet, 'Entre jeux de mains et jeux de mots'.

50 Jaquet and Sørensen, 'Historical European Martial Art', pp. 10-15, 19-20.

51 Jaquet, 'Experimenting Historical European Martial Arts, a Scientific Method?', pp. 234-40.

52 Jaquet and others, 'Range of Motion and Energy Cost of Locomotion of the Late Medieval Armoured Fighter'.
} 
fighting techniques is not. In the case of fighting, we are confronted with a reciprocal phenomenon of reaction that involves mind and body of a socialised counterpart. As I tried to point out above, fighting systems with their specific techniques have to be seen as part of a historical culture of fighting. They only exist within a given historical context and are transformed when taken into another context and performed by modern HEMA practitioners. 53

Though all embodied techniques have a functional component and the human body has certain relatively stable properties, fighting techniques do not just follow a paradigm of ahistorical functionalism. There is a difference between simple actions (such as executing a strike and applying force on a target, using a wrist lock or conducting a hip throw) based on relatively reliable properties of human bodies and the execution of complex fighting techniques based on the action-reaction-schemes described in the fight books. The simple question how a fighting technique "works" on a biomechanical level is therefore highly underdetermined. 54

Furthermore, as fighting is a contingent phenomenon of reciprocity and as the medieval counterpart is already dead for centuries, the results of modern reconstruction can only be tested in a modern context against the reactions of other modern practitioners and their socialised bodies. The recreation of fighting techniques therefore remains an equation with two or more unknowns. In the end, these equations cannot be solved but approximately.

Another neglected, yet important factor is the role of violence, pain and fear. Though it is not my intention to create a simplified imagination of the Middle Ages as an essentially violent period, we have to keep in mind that these techniques were mostly practiced and

53 "Technique consists of discoveries about specific material possibilities that can be repeated with some degree of reliability, so that what works in one context may also work in another. It is crucial to remember that this reliability is never more than relative. Often we are wrong in our expectations about the reliability of technique. Changes in the environment, or in our own embodiment, or the passage of technique from one context to another, can produce unexpected results." Spatz, What $a$ Body Can Do, p. 42.

54 See also Wetzler's observation that similar techniques are used in various fighting systems without having the same status in relation to the underlying concepts of fighting, their tactical considerations and their risk assessment. Wetzler, 'Martial Arts Studies as Kulturwissenschaft', p. 27. Peter Lorge makes a similar observation in regard to Chinese martial arts: "Because almost all martial arts in China and outside share a mostly identical palette of individual strikes, stances, and other techniques, what distinguishes one style from another is which techniques are not used, how techniques are combined, what forms one performs, and the emphasis given to certain techniques over others." Lorge, Chinese Martial Arts, p. 207. 
taught by violence professionals and that their apprentices had to or may have intended to use them in actual combat. 55

The techniques in question are thus by no means innocent or neutral. Although forms of non-lethal fighting clearly existed in the Middle Ages, either as part of cooperative training practices or as agonistic competition, the violent background of the techniques in question has to be considered. While most of today's martial arts practitioners and especially practitioners of HEMA living in relatively peaceful Western societies will have very few personal experiences with lethal force (which does not hinder some of them to extensively discuss the matter after training and on the internet), we have to keep in mind that the medieval techniques were actually intended to harm and kill other human beings. And that people from various social strata used them for exactly this purpose. The shift from a violent practice to either experiencing HEMA as convivial recreation of technique or experimenting it in a non-violent university context leads to a severe status change on the level of technique.

We furthermore cannot escape the uncomfortable, yet fundamental question: why do we want to recreate techniques designed for harming and killing people? ${ }^{56}$ The scientific study of medieval cultures of fighting therefore also has to reflect upon our perspectives on the researched subject, our interest in it, and the narratives that shape our contemporary discourses on violence and fighting. ${ }^{57}$

\section{THE AUTHENTICITY-DEBATE IN MUSICOLOGY}

Instead of relating HEMA to experimental archaeology, a comparison with medieval musicology could be more fruitful. While fighting is a phenomenon of reaction, music is a phenomenon of reception that is also depending on a socialised counterpart. Furthermore, the attempts to recreate the lost sound of medieval music through the study of surviving notation systems already began at the end of the $19^{\text {th }}$ century. The matter

\footnotetext{
55 See the abovementioned dimension "preparation for violent conflict" of martial arts as social institutions.

${ }^{56}$ Speaking not as a historian, but as a martial arts practitioner from early childhood on, the question is easy to answer: because it is intellectually and physically challenging and a lot of fun. The prerequisite for martial arts being fun is, however, exactly the abovementioned change of status from violent practice to cooperative training within a community of practitioners. In this context, I would like to refer to the campaign "Love Fighting, Hate Violence" (LFHV) initiated by Alex Channon and Christopher R. Matthews from the University of Brighton. They argue for a distinction between fighting and violence and discuss issues related to the notions of violation, consent and respect in the context of modern martial arts and combat sports. Matthews and Channon, 'Understanding Sports Violence'. See also: < http://www.lfhv.org >, accessed 15.10.2016.

57 Burkart, 'Zweikampfpraktiken zwischen sozialer Normierung, medialer Präsentation und wissenschaftlicher Einordnung', pp. 6-7; Burkart, 'Body Techniques of Combat'.
} 
was since then vividly discussed among musicologists. ${ }^{58}$ Like in HEMA, a movement of musical performers emerged that used replicas or even original instruments to interpret the early and incomplete notation systems in order to recreate the sound of medieval music. This so called Historical Performance (HP) movement dominated the discourse on the sound of medieval music for quite a long time. ${ }^{59}$

However, in the 1980's a debate on the status of these reconstructions began with the articles of Richard Taruskin. ${ }^{60}$ It reached its peak between 2002 and 2004 with the three monographs of Daniel Leech-Wilkinson, Anette Kreutziger-Herr and John Butt. ${ }^{11}$ One aspect at the heart of the debate was that the information on the performance of early music that could be derived from medieval records was so insufficient that its interpretation relied more on modern beliefs of performers than on actual evidence. Taruskin was one of the first musicologists to point out that the HP movement actually represented modernist concerns in musical taste and aesthetics, instead of re-creating a reliable "authentic" representation of the past. ${ }^{62}$

This line of thought was further developed by Leech-Wilkinson, who traced the fundamental changes in the way modern conceptions of medieval polyphony were converted into sound. His example is the voices-and-instruments versus the a capella hypothesis. While for $19^{\text {th }}$ century performers, the surviving notations of medieval songs were believed to be all vocal, this view changed at the beginning of the $20^{\text {th }}$ century. Now some parts of the notations were interpreted as representing instrumental preludes, interludes and postludes and the songs were associated with the conception of the German "Kunstlied" (artsong). Then, from the 1980s on, a "re-invention of the a capella hypothesis" took place, reverting the established "orthodoxy" in the performance of medieval music. ${ }^{63}$ Leech-Wilkinson draws upon these dramatic changes in the representation of past music as contemporary sound by analysing the impact of individual conviction, ideology and scholarly discourse on musical performance. He anticipates the results of his study in the following manner:

Almost everything we might wish to know about the sound of medieval music is lost to us. Without living in the Middle Ages and experiencing that culture we are never going to be able to make the sense of those fragments of evidence that was made of them when they were set

\footnotetext{
58 Kreutziger-Herr, 'Imagining Medieval Music', pp. 91-100.

${ }^{59}$ Huck, 'Meistererzählungen und Meistergesänge', pp. 69-71.

60 Taruskin, Text and Act.

${ }^{61}$ Leech-Wilkinson, The Modern Invention of Medieval Music, Kreutziger-Herr, Ein Traum vom Mittelalter; Butt, Playing with History.

62 Irving, 'Historicizing Performance Practice', p. 83.

${ }^{63}$ Leech-Wilkinson, The Modern Invention of Medieval Music, pp. 13-156.
} 
down. Even the things we recognise - that people set texts, sang and played instruments - can have no reality in sound except in so far as we can imagine them in relation to the way people sing and play around the world today. Ways of singing and ways of playing change too fast for us to be able to guess backwards. ${ }^{64}$

Concerning the status of modern re-creations of medieval music at the beginning of the $21^{\text {st }}$ century, no one still dares to speak of historical authenticity. ${ }^{65}$ Furthermore, the term "Historical Performance" is no longer used. The musicians interpreting medieval traces of music are instead referring to their work by using the more modest term "Historically Informed Performance" (HIP). ${ }^{66}$ The reasons for this development are very similar to the aspects I tried to highlight in this paper in regard to HEMA. ${ }^{67}$

\section{CONCLUSION}

In this article I have explored and theorised the relationship between past fighting practices structured by technique, attempts to communicate and codify techniques of fighting, the interpretation of these documents, and their translation into present practice. This theoretical outline has to be seen as preliminary work for a larger study on medieval and early modern fighting practices from the perspective of cultural history.

To explore the connections between actual human practice and their remaining tangible traces is at the heart of all endeavours of historical research. To read a fight book is therefore in many ways similar to reading Thomas Aquinas. To understand the thoughts and concepts expressed in Aquinas' writing, modern readers have to interpret them on the basis of their own socialized minds and their own habitus. "Understanding" medieval philosophy and theology therefore does not mean to have reached the state of mind of medieval contemporaries and no one would claim to have an "authentic" reading of Thomas Aquinas. Understanding his writings only means to be able to interpret these documents by giving them meaning within the limits of our contemporary discourses.

The same relationship applies to the reconstruction of embodied technique. Although almost no practitioner of HEMA openly claims that her interpretation would represent

\footnotetext{
64 Ibid., p. 4.

${ }^{65}$ Kreutziger-Herr, Ein Traum vom Mittelalter, p. 221.

${ }^{66}$ Huck, 'Meistererzählungen und Meistergesänge', p. 80.

${ }^{67}$ As an experiment of thought, I would recommend reading the studies on early music cited above, while replacing "music" with "fighting system" and the "sound of medieval music" with the "execution of medieval technique". It may not suit our discussed subject all the time, but it definitely raises questions that need further discussion.
} 
"authentic" medieval technique ${ }^{68}$, authenticity is still implicitly present in HEMA discourses as a desirable, yet only approximately achievable, goal reached by interpretations through thorough research. If we read the proposed scholarly methodologies from this perspective, it seems that through a compliance to scientific standards of research at least "more authentic" practices can be distinguished from "less authentic" interpretations.

Whilst the analogy between HEMA and its musical counterpart HP/HIP does not fit in every respect, the authenticity debate in musicology can stimulate the discourse on the status of modern (re)constructions of technique in several ways. The HP debate contains three similarities: 1) the problem of incomplete notation systems, 2) a broken tradition in the transmission of technique, and 3) the essential act of interpretation.

This way of looking at fight books helps to generate questions for future research, but it also points to the limits of my theoretical outline. I have argued that the main part of medieval fighting technique as knowledge is lost and not documented in the fight books. The attempts to interpret these traces of medieval technique and to put them into practice therefore have to be seen as modern constructions based on modern bodies and their "sedimented agency". HEMA thus represents a very modern form of swordplay which is only informed by the fight books. At the same time, this practice is also authorised and legitimised within our contemporary martial arts discourses by linking it to authentic medieval documents.

However, HEMA techniques are to be seen as the result of what can be called hermeneutics of movement and embodied research. Though purely modern technique, and by no means an "authentic" reconstruction of historical technique, the practice of HEMA represents a ground-breaking endeavour in generating new technique through "Practice as Research" (PaR). ${ }^{69}$

But what are the limits of these findings? What information would be needed to actually re-construct past technique? Is it for example possible to reconstruct techniques of military close quarters combat from the beginning of the $20^{\text {th }}$ century for which we have detailed manuals and even video footage? The problem is that the crucial part of

${ }^{68}$ Using some quick searches on Google as a first indication, it shows that "HEMA authentic" scores almost no HEMA related hits. This does, however, not apply to "authentic sword fighting" and "real sword fighting" where the number of HEMA related pages grows slightly. Yet, the main part of sites using this vocabulary of authenticity seems to be outsider's perceptions of HEMA. This is yet just a first impression and a thorough content analysis of HEMA sites and publications as well as media coverage on HEMA seems to be a promising project in the field of martial arts studies.

${ }^{69}$ Spatz, What a Body Can Do, pp. 217-50. See also the Journal of Embodied Research (to be launched in February 2017), which will be the first peer reviewed scholarly video essay journal entirely dedicated to practical research on embodied technique. 
embodied technique represents a form of tacit knowledge that cannot be recorded in books. Cases where the lines of tradition were not or not completely severed are therefore of special interest. Kendo, the sportive counterpart of Japanese swordplay, as well as different styles of Kenjutsu are still widely practised around the world today. Olympic fencing is at the same time directly linked to older, non-sportive styles of European fighting systems. If a (transformed) part of the original tacit knowledge is still present within these communities of practitioners, is it then possible to reconstruct a $17^{\text {th }}$ century Kenjutsu style? Or if trained sport-fencers are practising with rapiers according to early modern fight books, can these techniques be qualified as reconstructions?

The examples of Olympic fencing and Kendo furthermore point to the importance of the social context of fighting and the equipment used. The introduction of protective gear and the split bamboo shinai in the early $18^{\text {th }}$ century dramatically changed the way Kenjutsu techniques were executed. ${ }^{70}$ The same effects occur when a fighting system is transformed into a competitive sport, in the case of Olympic fencing. Techniques change if the context of fighting changes. Future research therefore has to address the relationship between fighting systems, fighting techniques, and the social context in which these techniques are practised and applied.

Concerning the incompleteness of early notation systems, one could also ask if technical opportunities like the omnipresence of video recording and the possibilities offered by motion capture and 3D filming enable us to actually record more knowledge of embodied technique than before. How far can we thus push the limits between tacit and explicit knowledge by the use of new media?

We furthermore have to investigate the relationship between fighting techniques and martial arts as social institutions. Following Michael Polanyi's above cited understanding of arts, we have to distinguish between the reconstruction of technique on the one hand and knowledge of the art on the other. Different martial arts might integrate very similar techniques very differently into wider systems of knowledge and social meaning. I would therefore argue that embodied techniques can be as polysemous as words, signs, and other symbols. To investigate the "semantic" and the "pragmatic" meaning of a specific technique is then closely connected to studying the status and significance of that technique within a specific fighting system and the related martial art. By abandoning essentialist conceptions of fighting techniques we might thus open up new pathways of research in the study of human culture.

This perspective is, however, neither limited to studies on fight books, nor on European martial arts traditions. There are also many Asian sources on fighting systems and even

${ }^{70}$ Bennett, Kendo, pp.73-85. 
attempts similar to HEMA, where practitioners try to revive these systems. ${ }^{71} \mathrm{I}$ hope that this theoretical sketch might help to stimulate transhistorical and transcultural comparisons on fighting practices, their social contexts, and the media that emerged in these cultures.

To conclude, I would like to return to Daniel Jaquet's important distinction between "experiencing" and "experimenting" swordplay. In my opinion, skill and practical experience in martial arts is crucial for the study of medieval fighting systems. It makes the practitioner-researcher aware of many aspects the non-practitioner would have no knowledge of. My understanding of the anonymous codex Nürnberg, Germanisches Nationalmuseum, ms. 3227a may serve as a personal example. I interpret the unfinished text fragments on fighting techniques as a collection of personal records of a scribe, who was taking notes while being trained in swordsmanship. ${ }^{72}$ The structure of the manuscript, which was very extensive at the beginning but was then aborted at a certain point, reminded me of my own notes taken during my black belt preparation in Shotokan Karate. My notes also stopped at a certain point when I no longer wrestled intellectually with the training concepts of my teacher, but had understood them with my body. This interpretation may or may not be correct, in any case it was based on personal experience in martial arts training that stimulated a different reading of an aborted text. It was, however, not based on a practical reconstruction of the techniques described in the codex 3227a. Modern swordsmanship may thus be central to the study of fight books. But it is in the same way as musicality and personal experience in performing music is for conducting research on medieval notation systems for polyphony.

Studying the fight books, comparing these records of technique with technical knowledge from existing martial arts from all over the world, and experiencing HEMA, will definitely raise the level of swordsmanship practiced today. This expertise among practitioners can on the scientific side open up new research questions relating to past cultures and their embodied knowledge.

At the same time, practically interpreting medieval sources on swordsmanship is always a way to generate public attention. With the martial arts craze of the 1970s the public interest in martial arts and their omnipresence in film and other media has steadily increased. By constructing a historically informed modern martial art based on the interpretation of fight books, the discipline of medieval studies might thus be able to get more public attention than it actually has. If this attention is directed carefully, this might

\footnotetext{
71 A very good example is a website run by the Historical Combat Association (Singapore) focusing on Chinese Ming Dynasty treatises on various weapons. The site provides English translations of source material as well as videos of practical interpretations. <www.chineselongsword.com>, accessed 16.10.2016.

72 Burkart, 'The Autograph of an Erudite Martial Artist'.
} 
also be a way to communicate general considerations on the central role of interpretation and on the constructed nature of history itself to a larger audience.

\section{BIBLIOGRAPHY}

\section{VIII.1. Primary sources}

Leeds, Royal Armouries, ms. I.33.

Nürnberg, Germanisches Nationalmuseum. ms. 3227a.

\section{VIII.2. Secondary sources}

Anglo, Sydney, The Martial Arts of Renaissance Europe (New Haven, CT: Yale University Press, 2000).

Bachmann-Medick, Doris, Cultural Turns: New Orientations in the Study of Culture, De Gruyter Textbook (Berlin, Boston: de Gruyter, 2016).

Barber, Richard, and Juliet Barker, Tournaments: Jousts, Chivalry and Pageants in the Middle Ages (Woodbridge: Boydell, 1989).

Bennett, Alexander, Kendo: Culture of the Sword (Oakland, California: University of California Press, 2015).

Boffa, Sergio, Les manuels de combat (Fechtbücher et Ringbücher), Typologie des sources du Moyen Âge occidental, 87 (Turnhout: Brepols, 2014).

Bowman, Paul, Martial Arts Studies: Disrupting Disciplinary Boundaries, Disruptions (London: Rowman \& Littlefield International, 2015).

Burkart, Eric, 'Body Techniques of Combat: The Depiction of a Personal Fighting System in the Fight Books of Hans Talhofer (1443-1467 CE)', in Killing and Being Killed. Perspectives on Bodies in Battle, ed. by Jörg Rogge [forthcoming].

Burkart, Eric, 'Den Kampf anhalten: Bildliche Bewegungsdidaktiken in moderner Ratgeberliteratur und in europäischen Handschriften des 14. und 15. Jahrhunderts', in »Die Welt anhalten«: Von Bildern, Fotografie und Wissenschaft, ed. by Günter Burkart and Nikolaus Meyer (Weinheim, Basel: Beltz Juventa, 2016), 174-201.

Burkart, Eric, 'Die Aufzeichnung des Nicht-Sagbaren: Annäherung an die kommunikative Funktion der Bilder in den Fechtbüchern des Hans Talhofer', in Zweikeämpfer: Fechtmeister - Kämpen - Samurai, ed. by Uwe Israel and Christian Jaser, Das Mittelalter. Perspektiven mediävistischer Forschung, 19.2 (Berlin: De Gruyter, 2014), 253-301. 
Burkart, Eric, 'The Autograph of an Erudite Martial Artist: A Close Reading of Nuremberg, Germanisches Nationalmuseum, Hs. 3227a', in Late Medieval and Early Modern Fight Books: Transmission and Tradition of Martial Arts in Europe (14th-17th Centuries), ed. by Daniel Jaquet, Karin Verelst and Timothy Dawson, History of Warfare, 112 (Leiden, Boston: Brill, 2016), 451-80.

Burkart, Eric, 'Zweikampfpraktiken zwischen sozialer Normierung, medialer Präsentation und wissenschaftlicher Einordnung', in Agon und Distinktion: Soziale Räume des Zweikampfs zwischen Mittelalter und Neuzeit, ed. by Uwe Israel and Christian Jaser, Geschichte, Forschung und Wissenschaft, 47 (Berlin, Münster: LIT, 2016), 414.

Burke, Peter, What is Cultural History? (Cambridge, U.K., Malden, MA: Polity Press, 2004).

Butt, John, Playing with History: The Historical Approach to Musical Performance, Musical Performance and Reception (Cambridge: Cambridge University Press, 2004).

Daniel, Ute, Kompendium Kulturgeschichte: Theorien, Praxis, Schlüsselwörter, 5th edn (Frankfurt a. M.: Suhrkamp, 2006).

Forgeng, Jeffrey L., The Medieval Art of Swordsmanship: A Facsimile \& Translation of Europe's Oldest Personal Combat Treatise, Royal Armouries MS I.33 (Union City: Chivalry Bookshelf, 2003).

Frank, Adam D., Taijiquan and the Search for the Little Old Chinese Man: Understanding Identity Through Martial Arts (New York: Palgrave Macmillan, 2006).

Grondin, Jean, 'The Hermeneutical Circle', in The Blackwell Companion to Hermeneutics, ed. by Niall Keane and Chris Lawn, Blackwell Companions to Philosophy, 60 (Chichester, West Sussex, UK, Malden, MA: John Wiley \& Sons, 2016), 299-305.

Huck, Oliver, 'Meistererzählungen und Meistergesänge: Geschichte und Aufführung der Musik des Mittelalters', in Meistererzählungen vom Mittelalter: Epochenimaginationen und Verlaufsmuster in der Praxis mediävistischer Disziplinen, ed. by Frank Rexroth, Historische Zeitschrift - Beiheft, N.F., 46 (München: Oldenbourg, 2007), 69-85.

Irving, David R. M., 'Historicizing Performance Practice: Early Music through Time and Space', Early Music, 41.1 (2013), 83-85.

Israel, Uwe, and Christian Jaser, eds, Agon und Distinktion: Soziale Räume des Zweikampfs zwischen Mittelalter und Neuzeit, Geschichte, Forschung und Wissenschaft, 47 (Berlin, Münster: LIT, 2016).

Jaquet, Daniel, and Claus F. Sørensen, 'Historical European Martial Art - A Crossroad between Academic Research, Martial Heritage Re-creation and Martial Sport Practices', Acta Periodica Duellatorum, 1 (2015), 5-35.

Jaquet, Daniel, and Nicolas Baptiste, eds, Expérimenter le maniement des armes à la fin du Moyen Age: Experimente zur W affenhandhabung im Spätmittelalter, Itinera, 39 (Basel:

Schwabe, 2016). 
Jaquet, Daniel and others, 'Range of Motion and Energy Cost of Locomotion of the Late Medieval Armoured Fighter: A Proof of Concept of Confronting the Medieval Technical Literature with Modern Movement Analysis', Historical Methods: A Journal of Quantitative and Interdisciplinary History, 49.3 (2016), 169-86.

Jaquet, Daniel, Combattre en armure à la fin du Moyen Âge et au début de la Renaissance d'après les livres du combat (Thèse de doctorat, Université de Genève, 2013).

Jaquet, Daniel, 'Entre jeux de mains et jeux de mots: faire l'expérience ou expérimenter les gestes d'après les textes techniques. Reproduire ou répliquer les objets...', in Expérimenter le maniement des armes à la fin du Moyen Age: Experimente zur Waffenhandhabung im Spätmittelalter, ed. by Daniel Jaquet and Nicolas Baptiste, Itinera, 39 (Basel: Schwabe, 2016), 11-18.

Jaquet, Daniel, 'Experimenting Historical European Martial Arts, a Scientific Method?', in Late Medieval and Early Modern Fight Books: Transmission and Tradition of Martial Arts in Europe (14th-17th Centuries), ed. by Daniel Jaquet, Karin Verelst and Timothy Dawson, History of Warfare, 112 (Leiden, Boston: Brill, 2016), 216-43.

Jaquet, Daniel, Karin Verelst, and Timothy Dawson, eds, Late Medieval and Early Modern Fight Books: Transmission and Tradition of Martial Arts in Europe (14th-17th Centuries), History of Warfare, 112 (Leiden, Boston: Brill, 2016).

Jaquet, Daniel, ed., L'art chevaleresque du combat: Le maniement des armes à travers les livres de combat (XIVe-XVTe siècles) (Neuchâtel: Éditions Alphil-Presses universitaires suisses, 2013).

Jinnah, Naila, 'Swimming, United States', in Sports around the World: History, Culture, and Practice, ed. by Charles Parrish and John Nauright (Santa Barbara, CA: ABC-CLIO, 2012), vol. 3, 400-05.

Judkins, Benjamin N., 'The Seven Forms of Lightsaber Combat: Hyper-reality and the Invention of the Martial Arts', Martial Arts Studies, 2 (2016), 6-22.

Keen, Maurice H., Chivalry (New Haven: Yale University Press, 1984).

Kreutziger-Herr, Annette, Ein Traum vom Mittelalter: Die Wiederentdeckung mittelalterlicher Musike in der Neuzeit (Köln: Böhlau, 2003).

Kreutziger-Herr, Annette, 'Imagining Medieval Music: A Short History', in Correspondences: Medievalism in Scholarship and the Arts, ed. by Thomas A. Shippey, Studies in Medievalism, 14 (Cambridge: Brewer, 2005), 81-109.

Landwehr, Achim, Kulturgeschichte, (Stuttgart: Ulmer, 2009).

Leech-Wilkinson, Daniel, The Modern Invention of Medieval Music: Scholarship, Ideology, Performance, Musical Performance and Reception (Cambridge: Cambridge University Press, 2002).

Leng, Rainer, Fecht- und Ringbücher, Katalog der deutschsprachigen illustrierten Handschriften des Mittelalters, Bd. 4/2, Lfg. 1/2, Stoffgr. 38 (München: C.H. Beck, 2008). 
Lorge, Peter A., Chinese Martial Arts: From Antiquity to the Twenty-first Century (New York: Cambridge University Press, 2012).

Ludwig, Ulrike, Barbara Krug-Richter, and Gerd Schwerhoff, eds, Das Duell: Ehrenkämpfe vom Mittelalter bis zur Moderne, Konflikte und Kultur - Historische Perspektiven, 23 (Konstanz: UVK, 2012).

Ludwig, Ulrike, Das Duell im Alten Reich: Transformation und Variationen frühneuzeitlicher Ehrkonflikte, Historische Forschungen, 112 (Berlin: Duncker \& Humblot, 2016).

Matthews, Christopher R., and Alex Channon, 'Understanding Sports Violence: Revisiting Foundational Explorations', Sport in Society (2016), 1-17.

Mauss, Marcel, 'Body Techniques', in Sociology and Psychology: Essays (London: Routledge and K. Paul, 1979), 95-123.

Mauss, Marcel, 'Les techniques du corps', Journal de Psychologie, 32.3-4 (1935), 271-93.

Polanyi, Michael, Personal Knowledge: Towards a Post-Critical Philosophy (Chicago, 1958).

Price, Brian R., 'A Proposed Methodology for the Validation of Historical European Martial Arts', Initial. A Review of Medieval Studies, 3 (2015), 57-70.

Reckwitz, Andreas, Die Transformation der Kulturtheorien: Zur Entwicklung eines Theorieprogramms, 3rd edn (Weilerswist: Velbrück, 2012).

Riemer, Nick, Introducing Semantics, Cambridge Introductions to Language and Linguistics (Cambridge, New York: Cambridge University Press, 2010).

Spatz, Ben, What a Body Can Do: Technique as Knowledge, Practice as Research (Abingdon: Routledge, 2015).

Taruskin, Richard, Text and Act: Essays on Music and Performance (Oxford, New York: Oxford University Press, 1995).

Tlusty, Ann, The Martial Ethic in Early Modern Germany: Civic Duty and the Right of Arms, Early Modern History: Society and Culture (Basingstoke: Palgrave Macmillan, 2011).

Wacquant, Loïc J. D., Body \& Soul: Notebooks of an Apprentice Boxer (Oxford, New York: Oxford University Press, 2004).

Wetzler, Sixt, 'Martial Arts Studies as Kulturwissenschaft: A Possible Theoretical Framework', Martial Arts Studies, 1 (2015), 20-33.

Wetzler, Sixt, 'Vergleichende Kampfkunstwissenschaft als historischkulturwissenschaftliche Disziplin: Mögliche Gegenstände, nötige Quellen, anzuwendende Methoden', in Menschen im Zweikampf - Kampfleunst und Kampfsport in Lehre und Forschung 2013: Jahrestagung der dvs-Kommission "Kampfleunst und Kampfsport" vom 7.-9. November 2013 in Erlangen, ed. by Sebastian Liebl and Peter Kuhn, Schriften der Deutschen Vereinigung für Sportwissenschaft, 236 (Hamburg: Feldhaus, 2014), 57-66.

Zarrilli, Phillip B., When the Body Becomes All Eyes: Paradigms, Discourses and Practices of Power in Kalarippayattu, a South Indian Martial Art (Delhi: Oxford University Press, 1998). 